\title{
衛星リモートセンシングによる 農業的土地利用の調査
}

\author{
佐 藤 哲 夫* \\ Agricultural Land Use Survey by Satellite Remote Sensing \\ Tetsuo SATOH
}

\begin{abstract}
In spite of such well-known merits as large scope of semi-real-time, periodical digital data image, remote sensing has not come into practical use yet in the field of agricultural land use survey in Japan, not only because of its rough resolution for Japanese arable land and poor cloud condition during main farming season, but also because of insufficient regional theory of agricultural economics which concerns with regional analysis in agricultural area.
\end{abstract}

Generally speaking, agricultural land use survey in Japan has been made for the purpose of understanding evolution of peasant economy through cropping system analysis and therefore it has not necessarily been abound in regional implications. But recently the concept of local agricultural system, which consists of villages as substantial and spatial units of farming, appears to express a significant object of governmental agricultural policy and this goes especially for recent paddy conversion programme. With this change of management theory, agricultural land use survey by village is becoming more essential for economic land classification which is now rather regionalization by social condition of farming than evaluation of potentiality of land for which it was ordinally intended.

Because long-term and nation-wide survey is necessary to map out a new strategy of rice production, remote sensing data can be applied, for the moment, to monitor distribution of paddy conversion. On a techinical point, it is not very difficult to extract paddy field and upland field.

According to a case study in this article, Landsat data, which is standerdized on UTM coordinated so that other data and cartographic information including village boundary, can give us general view of land use as well as converted paddy distribution even at village level (Photo 2, Photo 4, Photo 6), and it suggests a possibility to find new factors of land use change through remote sensing data analysis. However estimation of the area by Landsat data differs from seasons and rarely corresponds with census data. Improving quantitative accuracy and stability of seasonal and serial data should be the most urgent problem for forthcoming agricultural land use survey by satellite remote sensing.

* 東京大学教跮学部 Faculty of Arts and Sciences, University of Tokyo 


\section{I. 衛星リモートセンシングの譨業分野への応用}

陸域を対象とした衛星リモートセンシングの中で, 現在最も一般的に利用されているのはランドサ ットMSS データであろう。農業分野では，これまでに作物の作付け面積や作況の推定（神山・宇田川 1981, 芝山ほか 1981), 冷害, 降灰などの災害調査（哚山・安田 1981, 渡辺ほか 1981, 深山ほか 1983, 高畑ほか 1978), 土壤図の作成（福原ほか 1979, 安田ほか 1980, 斎藤ほか 1985）などが行な われた。さらに，それらの技術を応用し，農地としての開発適性を評価する資料作成も，開発途上国に対 する技術協力で試みられている（那須 1981, 国際協力事業団 1983, 秋山・樑山 1984) ${ }^{1}$ 。これらの調 查に, 衛星リモートセンシングを利用することの利点としては, 以下のようなものが考えられる。

第一は広域性に優れている点である。空中写真に比較すれば精度はかなり落ちるが, 広域のほぼ同時点 の状況を同程度の精度で把握することができる。最近はマイコンによる利用も可能になったので2), 大型 の装置は必ずしも必要でなくなり, 費用面での有利性にも注目されている。

第二は観測周期が短い点である。空中写真の撮影は, 国土地理院の場合でも三年から五年毎なのに対し, ランドサットデータの場合には毎年一回程度は画像を得られるので, 比較的新しい情報を利用することが できる。

第三はメッシュに準ずるデータとして利用できる点である。国土情報などとの重ね合わせは容易で，空 間的なモデルにも利用可能である。定型的な処理ならば迅速に行なうことができる。

他方, 衛星リモートセンシングの農業部門での利用には大きな障害もある。

第一は天候に支配される点である。衛星は二週間程度の周期で観測を行なっているが, 雲や大気中の水 蒸気のために鮮明な画像を得られないことが多い。特に農作物の生育期は雨期にあたるため, 最も重要な 情報は得にくい状態にある。第 1 図は過去に得られた雲量 $20 \%$ 末満の画像数を月別シーン別に整理したも のであるが3)，これによれば最も安定して画像が得られるのは12 月から 2 月にかけての北海道東部と関東

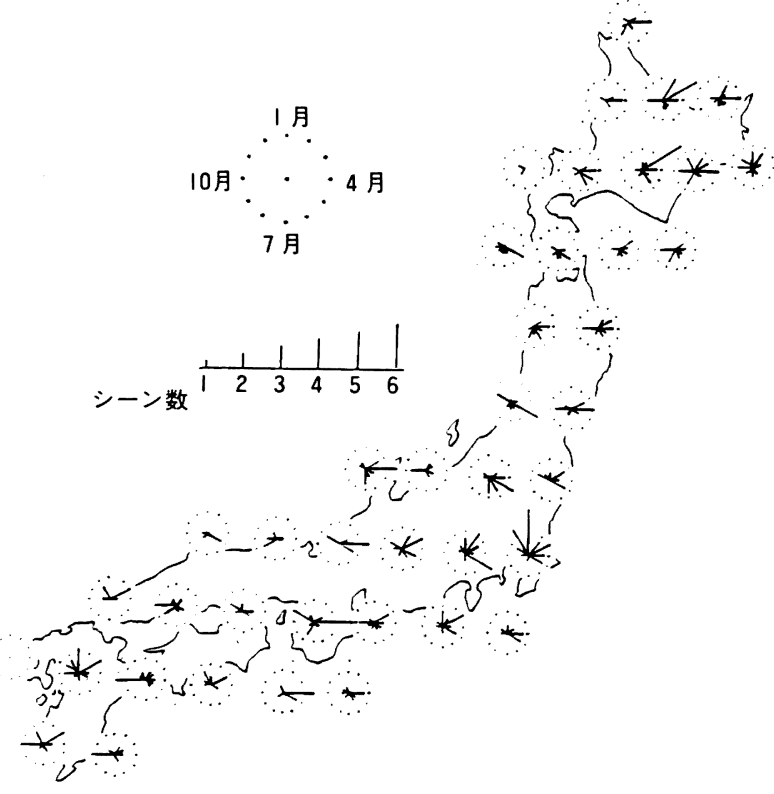

第 1 図 月別, シーン別雲量 $20 \%$ 未満のランドサット画 像数 (1979-1984) 地方であり, 逆に 6 月から 9 月にかけ ては全国的に画像を得にくいことがわ かる。

障害の第二は季節的な制約が大きい 点である。夏作物の収穫期にあたる 9 月から10月，代かきや冬作物の収穫が 重なる 4 月末から 5 月の画像は, 同一 作物の作付地であっても，土地被覆が 異なる可能性があるため, 土地利用調 査のデータとしては好ましくない。

第三は解像力が粗すぎる点である。 ランドサットDでは地上分解能 $30 \mathrm{~m} の$ セマティックマッパーを利用できるよ うになったが, 日本の土地利用の混在 の程度を考えると, 依然として不十分 である。都市周辺での小規模な宅地開 発に加えて, 水田の場合には大区画の 阑場は造りにくく, 畑地での農業生産 を中心とする諸国とは事情が異なる。 その他にも, ランドサットMSS の 
4 バンドが必ずしも植物の生体量推定に適切ではない（秋山・芝山 1985など）といった点や，山間部, 谷地に影が生ずるなどの問題点も指摘されている。

いずれにせよ定量的精確性が低いため, 農業分野での衛星リモートセンシングの利用は, 依然として試 験研究の段階に止っている。とくに農業地域の地域分析と係わりの深い経営・経済部門での応用は少ない と言えるが, それには研究の枠組み自体の問題もある。つまりこれまでの農業経営研究の中に地域を単位 とした分析が明確に位置付けられていなかったことにもよる。本来リモートセンシングは情報と雑音を峻 別して目的に応した画像を得る過程とも言える。従って何を探査しょうとしているのか，判別の基準を予 め設定しておく必要がある。そこで本稿では衛星リモートセンシングによる土地利用調査の結果を, 日本 の農業地域分析にどのような形で導入することができるか，その見通しを述べるために，土地利用調查の 意義を検討し，ランドサットデータ処理の具体例を示してみる。

\section{II. 日本における㖘業的土地利用調査の意義}

米国では農業分野の土地利用調査に早くから空中写真が利用されていたため, リモートセンシングも抵 抗なく受け入れられたと考えられる。しかし，米国での利用法をそのまま日本で適用することは現実的で はない。両国では農業の状況が全く異なっているうえ, 土地利用調査の目的や方法がかなり違っているか らである。

米国の農業地域の場合，かなり高高度の空中写真でも戋場の把握が十分可能であり，さらにそれらの機 能的結合と言える農場は, 経営的にも空間的にも実質的な単位と見なし得る。農場を単位とした土地利用 調査の結果は, 無謀な入植や経営規模执大, それに対する融資を防ぐための, 一種の計画地域区分である 経済的土地分級の過程に生かされてきだ。これれに対し日本の固場は小面積でその所有者・耕作者は錯綜 しており, 空間的な把握が難しい。概して言えば，日本でこれまで行なわれて来た土地利用調查は, 主に 作付体系の農法論的な分析を通して個別経営の発展方向を把握することを目的としていたものが多く, 地 域的な分析は副次的なものだったと言える。

日本でも開拓適地の選定が行なわれた時期はあったが（農林水産技術会議事務局編 1964), 高度経済成 長が始まってからは他産業との土地利用の競合が問題化し, 経済的土地分級はむしろ既存の農地保全のた めの，「優良農地」の規定とその区域指定として考えられるようになった。しかし，土地の経済的な評価の 必要性が高まったのとは逆に, 他方ではその基喏となる現実的な地代の算出はますます困難になった。農 地価格が農業地代の還元価額から大きく乘離し, また生産費の階層間格差が拡大したためである。その結 果, 農業経営の担い手の性格, 例えば土地の資産化につながる兼業化の程度や, 生産性に反映する経営規 模の動向などが重視されるようになり，さらにそれを空間的な広がりとして把握するために，分析の単位 を「集落」に取らさるを得なくなった。

このように現在の経済的土地分級は, 作物栽培上の土地条件評価にとどまらず, 経営形態をも指標に含 めた農業地域区分としての性格を強めている。しかしその反面, 本来, 社会的な概念であるはずの「集落」 が空間的な単位として有効か，とくに農業経営にどれほどの意味を持つか検討の余地は残されていると言 える。

一方, 行政においても地域農政に対する関心の高まりと共に, 地域農業計画作成のための地域分析の重 要性が強く認識されるようになってきた。最近では市町村程度の地域でも, その内部は均質な農業地域と は言い難くなっており, 自治体や農業団体が積極的に地域内調整を行なうべき時代になった（高橋・森 1978)。「80年代農政の基本方針」では，「地域ぐるみでの農業諸資源の有効利用」をうたっているが，それ は集落程度の地域組織を生産活動の単位とする考え方に根ざしている。土地利用型農業の場合には, 中核 農家を農業生産の中心的な担い手として農地を集団的に利用し，団地化・汎用化をすすめていくという発 展方向が考えられている。 
そのような構造政策的な含みを具体的に反映しているものとして，現在行なわれている米の生産調整， すなわち水田利用再編対策があげられる。これは, 予約限度数量と転作等目標面積の配分の二側面から行 なわれる。両者とも政府による都道府県間調整，都道府県による市町村間調整，市町村による農業者間調 整という段階を経て農家に割り当てられるのだが，農業者間調整は集落組織を通じて行なわれるのが普通 である。集落をどう扱うかは原則的には市町村に任されているのだが，計画地区（集落程度）ごとの計画 書の提出によって転作奨励金の上乗せを行なう計画加算や，転作圃場の連坦による団地化加算が取り入れ られており，集落組織の調整機能を積極的に利用しようとしている姿勢がうかがわれる。

このように農業経営を個別経営内部で完結したものとしてではなく，地域全体の中でとらえようとする 考え方や, 都道府県一市町村一集落といった地域的な階層構造への注目などは，水田を中心とする土地利 用調整の過程を通じて定着してきたものである。産業間での土地資源の配分, 農業部門内部での土地利用 調整，いずれを問題にするにしても，今後は地域を単位とした広域の土地利用調査の重要性がますます高 まると思われる。

\section{III. ランドサットデータによる農業的土地利用変化の把握}

\section{1） データ処理の体系}

農業分野でリモートセンシングを利用しようとする場合に，最も基䃈的な技術として必要になるのは土 地利用判別である。土壤図の作成や収量予測を行なうにしても，先ず農地を抽出する必要がある。しかし 周知の通り, リモートセンシングによって得られるデータは土地被覆であって土地利用ではない。衛星リ モートセンシングの場合には, 農業的土地利用に関しても, ゴルフ場と草地の判別が困難であること, 山 間部の伐採跡地や自然草地が畑や牧草地に判別される可能性があることなどの問題があり，分類項目を十 分に吟味する必要がある。リモートセンシング研究会（1981）では土地被覆に五つの大分類項目を設け, その下に細分類項目を設けている（第1 表)。さらに大きい区分として, 植生の乏しいもの（都市, 裸地), 植生の豊富なもの（森林, 農地・草地), 水域の区分を設ける場合もある（中島 1982）。もちろんこれら は一般的な項目であって, シーンによっては相互の判別の精度が低い場合があるし，対象地域内に十分な グランドトルスが得られない場合もある。

前節で述べたような社会的背景と技術的な可能性を考え合わせると，衛星りモートセンシングによる農

第 1 表 ランドサットデータを用いた土地被 覆分類

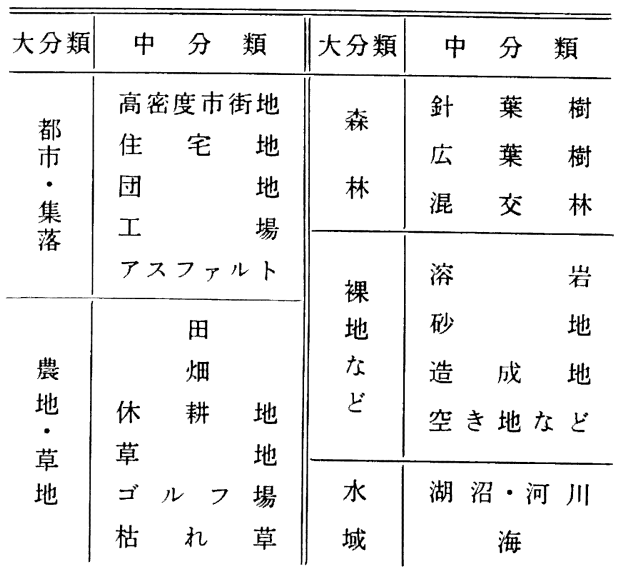

(日本リモートセンシング研究会 (1981) より)
業分野の土地利用調查は，当面は農地転用や水田転作 の状況把握に適用するのが現実的と思われる。土や植 生に乏しい市街地の抽出，また一定期間湛水状態とな る水田の判別は比較的容易である。また米の生産過剩 は構造的なもので, 水稲の栽培地域は全国的に分布し ているので，長期間にわたる広域の調查と対策が求め られており, 衛星りモートセンシング向きの課題と言 えよう。

判別の結果は集落単位で集計や分析が行なえるよう に整理する必要があり, さらに市街化区域や農振地域 の指定などの用途規制図や土壤図，土地基盤整備状況 図などの資料との重ね合わせもできるようにしておく ことが望ましい。地図情報や他のリモートセンシング データ, 他時期のデータとの重ね合わせを可能にする ためには，UTM 座標上のメッシュで統一規格を定 め, それに合わせて座標変換を行なう必要がある。グ 
ランドトルスデータも，最近の土地利用 図や地形図から UTM 座標で拾い出し ておく。これらの点を考慮して作成した 第 2 図の体系に従って, 実際にランドサ ットデータの処理を行なった例を次に検 討する。

\section{2）对象地域の土地利用の特色}

ここで対象地域として取り上げた杤木 県黒磯市は, 那須ヶ原の北半を占める位 置にあり,作目構成や経営規模から見て, 典型的な土地利用型農業地域と言うこと ができる。具体的には稲作と草地酪農を 農業生産の中心にしており, 1980年の数 字で見ると水稲 $2928 \mathrm{ha}$, 飼料作物 1470 ha, 牧草 1274 ha が農作物収穫面積の大 部分を占める(経営耕地総面積 $5471 \mathrm{ha}$ )。 また一戸当たりの経営規模は, 水田が $1.8 \mathrm{ha}$, 酪農が16頭と比較的大きい。こ れだけの大規模経営が成立したのは，平 地林の本格的な開発が戦後まで持ち越さ れたためである。

昭和30年代, 揚水機の性能の向上や平 地林の開墾によって揚水開田が著しく進 展し, 一方, 地下水位の低い北部の戦後 開拓地には酪農が搪がった。しかし昭和 40年代半ばを過ぎると, 米の生産調整が 始まって, 開田の意欲が低下すると同時 に, 酪農でも乳質改善運動によって専業 化が著しく進み, 稲作地域と酪農地域の 分化が明確になった。さらに市街地周辺 では工場の地方分散, 別荘地開発, 東北

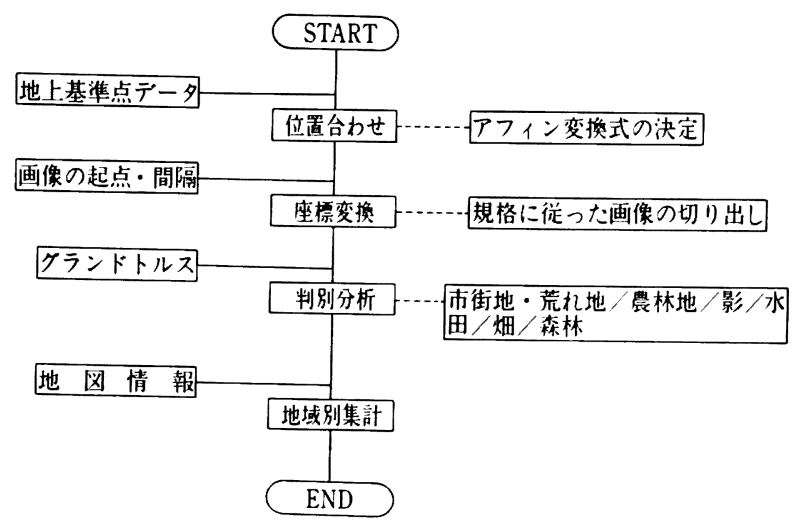

第 2 図 データ処理の流れ図

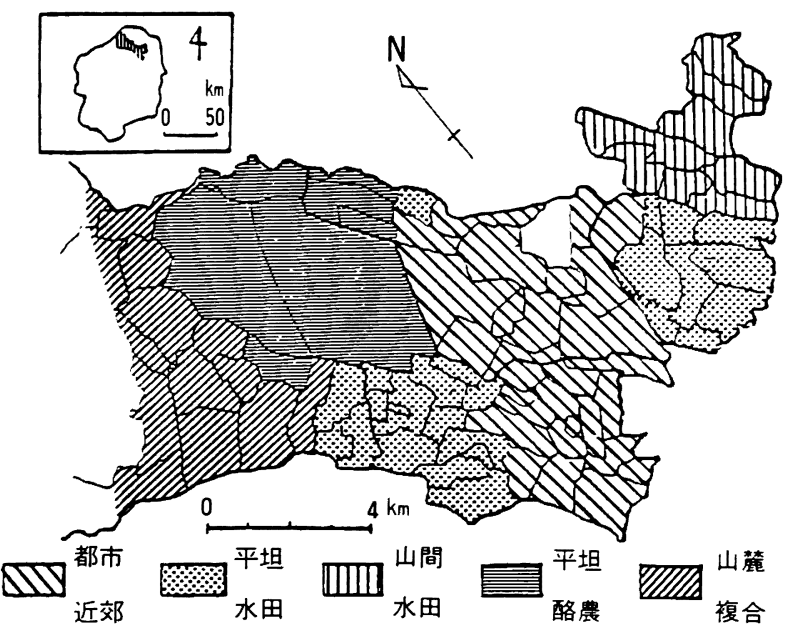

第3 図黒磯市の集落界および農業改良普及所による 農業地帯区分

自動車道の建設により, 農地や林地の転用が急増し, 市内には性格が大きく異なる農業地域が形成されて きた (第 3 図)。最近の土地利用の問題としては，次の三点が指摘されている。

第一は昭和50年代半ばから，市街地化が再び活発になり始めたことである。農地の潰廃は以前ほど激し くないが, 住宅地周辺では畜産公害が問題にされはじめている。

第二は北部山麓地帯の造成農地の利用方式が確立していない点である。瘦地で磷が多く，土壤改良の必 要があると言われる。加えて, 経営の担い手と成り得る中核農家が少ない。

第三は米および牛乳の生産調整の問題である。酪農地区が水田転作に積極的で, 市全体の実績が達成超 過となった結果，市町村間調整で転作目標面積の割り当てが増大し，市が積極的に集落間調整を行なわざ るを得ない状態になった。酪農地区での転用実績を高めた要因としては, 水稲の単収が市の基準単収より 低く，転作奖励金による補鰂が必ずしも不利でなかったこと，さらに昭和 54 年から牛乳の生産調整が開始 されて, 酪農家が飼料基盤の整備に力を入れ始めたことなどが挙げられる。 


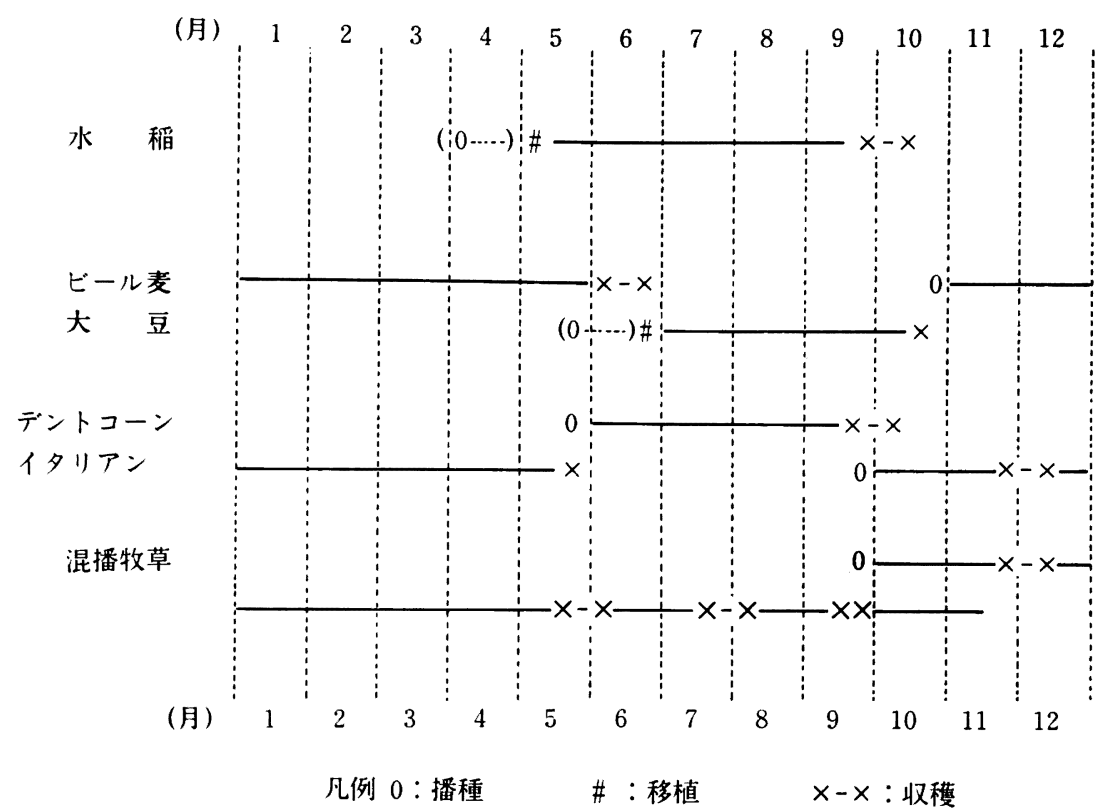

第 4 図 黒磯市周辺の主な農作物の作期

第 2 表 土地被覆分類項目

\begin{tabular}{|c|c|c|c|}
\hline $\begin{array}{l}1 \text { 次 } \\
\text { 区分 }\end{array}$ & $\begin{array}{l}2 \text { 次 } \\
\text { 区分 }\end{array}$ & $\begin{array}{l}3 \text { 次 } \\
\text { 区分 }\end{array}$ & 備 \\
\hline \multirow{3}{*}{$\begin{array}{l}\text { 植生 } \\
\text { 寒少 }\end{array}$} & \multicolumn{2}{|c|}{ 市街地 } & 商店街, 住宅地, 工場 \\
\hline & \multicolumn{2}{|c|}{ 荒れ地 } & 主に水無川の河道 \\
\hline & 水 & 水田 $\mathrm{A}$ & 灰色低地土㙥 \\
\hline 植 & 田 & 水田 B & 多湿黒ボク土壤 \\
\hline 典 & \multicolumn{2}{|c|}{ 畑 地 } & 主に飼料作物，牧草畑 \\
\hline \multirow[t]{2}{*}{ 富 } & 森 & 森林 A & 針苯樹林 (主に平地林) \\
\hline & 林 & 森林 B & 広葉樹林（主に山林） \\
\hline 影 & & & 山の北東斜面 \\
\hline
\end{tabular}

第 3 表 判別に用いた変数
(1) Band 4
(2) Band 5
(3) Band 6
(4) Band 7
(5) Band $7 /$ Band 4
(6) Band $6 /$ Band 5
(7) Band $7 /$ Band 5
(8) (Band 6-Band 4) $/$ (Band 6-Band 5)
(9) (Band 7-Band 4) $/$ (Band 7-Band 5)
(10) (Band $6+$ Band 7$) /($ Band $4+$ Band 5$)$

\section{3）分類画像の作成}

対象地域の大きさは $25 \mathrm{~km} \times 20 \mathrm{~km}$ の範囲に十 分おさまるので，記憶媒体はフロッピーディスク で十分であり，マイコンによる処理を試みた。出力画像の北西隅を $37^{\circ} 04^{\prime} \mathrm{N}-139^{\circ} 53^{\prime} \mathrm{E}$ として, UTM 座

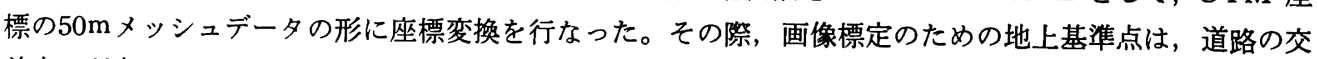
差点など各シーンに10点ずつ配置し，座標変換式にはアフィン変換を用いて，最近粼法により内挿した。 放射量補正は行なっていない。 分析に使用したデータは1979年 5 月 21 日（シーン1），79年11月 8 日（シーン 2)，80年11月11日（シー ン 3 )，81年 4 月 22 日（シーン 4 ）（以上ランドサット $2 ， 3$ 号)，82年10月 22 日（シーン 5 ）（ランドサッ ト 4 号）の 5 シーンである。第 4 図には黒磯周辺の主要な農作物の作期を示したが, これによればシーン 
衛星リモートセンシングによる農業的土地利用の調査

第 4 表 グランドトルスの分類結果（79年 5 月のシーン）

\begin{tabular}{|c|c|c|c|c|c|c|c|c|c|c|c|c|c|}
\hline $\begin{array}{l}ク \\
r\end{array}$ & $\overline{\text { ラン }}$ & & $\begin{array}{l}\text { サンプ } \\
\text { ルの数 }\end{array}$ & 1. & 2. & $\begin{array}{l}\text { 別 } \\
3 .\end{array}$ & $\begin{array}{l}\text { 扎 } \\
4 .\end{array}$ & $\begin{array}{l}=ク^{\circ} \\
5 .\end{array}$ & $\begin{array}{l}- \\
6 .\end{array}$ & 7. & 8. & 計 & 精 度 \\
\hline 1. & 市 街 & 地 & 125 & 69 & 22 & 5 & 4 & 0 & 0 & 0 & 0 & 100 & 69 \\
\hline 2. & 荒 れ & & 135 & 38 & 39 & 16 & 1 & 0 & 1 & 4 & 1 & 100 & 39 \\
\hline 3. & 水 田 & A & 149 & 11 & 2 & 36 & 28 & 28 & 7 & 7 & 1 & 100 & 36 \\
\hline 4. & 水 田 & B & 108 & 12 & 0 & 22 & 64 & 0 & 2 & 0 & 0 & 100 & 64 \\
\hline 5. & 畑 & 地 & 250 & 0 & 1 & 11 & 2 & 52 & 20 & 11 & 3 & 100 & 52 \\
\hline 6. & 森 林 & A & 250 & 1 & 0 & 11 & 1 & 4 & 73 & 9 & 1 & 100 & 73 \\
\hline 7. & 森 林 & B & 231 & 0 & 4 & 2 & 2 & 16 & 33 & 20 & 23 & 100 & 20 \\
\hline 8. & 影 & & 108 & 0 & 5 & 6 & 7 & 11 & 19 & 15 & 37 & 100 & 37 \\
\hline
\end{tabular}

第 5 表 グランドトルスの分類結果（79年11月のシーン）

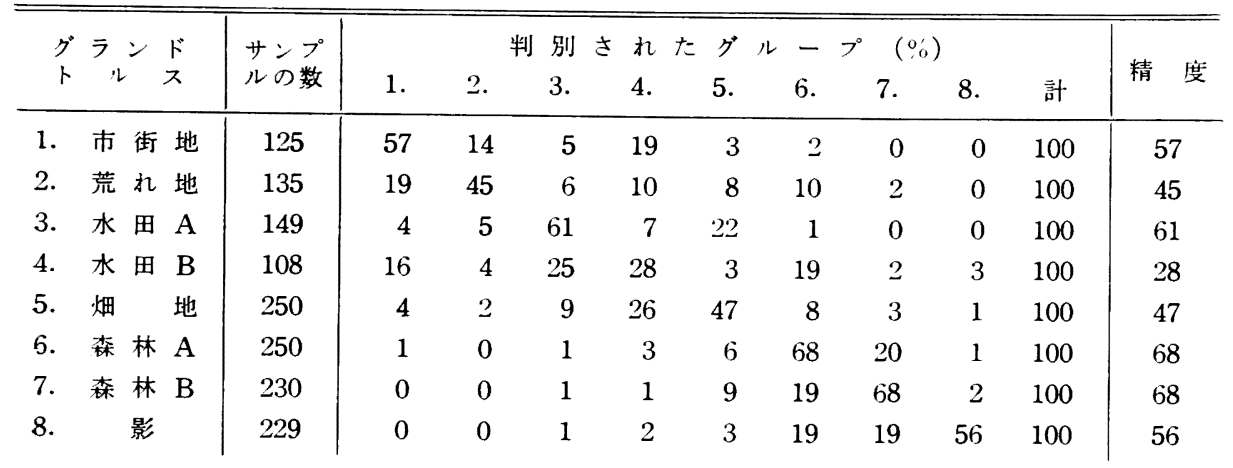

第 6 表 2 段階に分けた場合の判別結果（シーン1）

\begin{tabular}{|c|c|c|c|c|c|c|c|c|}
\hline & & \multirow{2}{*}{\begin{tabular}{lll}
+ & \multicolumn{2}{r}{} \\
ル & 数
\end{tabular}} & \multicolumn{5}{|c|}{ 判別されたグループ（\%) } & \multirow{2}{*}{$\begin{array}{c}\text { 精 }(\%) \text { 度 } \\
(\%)\end{array}$} \\
\hline & & & I & II (1) & (2) & (3) & III & \\
\hline I & $\begin{array}{c}\text { 市 街 地/荒 れ 地 } \\
(\mathrm{G} 1, \mathrm{G} 2)\end{array}$ & 260 & 91 & \multicolumn{3}{|c|}{6} & 3 & 91 \\
\hline II & 農林地（G 3-G 7) & 666 & 15 & \multicolumn{3}{|c|}{71} & \multirow[t]{4}{*}{14} & 71 \\
\hline & (1) 水田 (G 3,4) & 257 & & 82 & 8 & 10 & & 82 \\
\hline & (2) 畑 (G 5) & 250 & & 11 & 58 & 31 & & 58 \\
\hline & (3) 森林 (G 6, 7) & 481 & & 48 & 19 & 13 & & 73 \\
\hline & $\left(\mathrm{G}^{\text {影 }} 8\right)$ & 108 & 6 & \multicolumn{3}{|c|}{41} & 53 & 53 \\
\hline
\end{tabular}

1,2 は79年の, シーン 3,4 は80年の圃場利用形態を示すと考えられる。

土地被覆分類には第 2 表に示した項目を設けた。水域はほとんど無いので無視し, 代わって山間部森林 地帯にみられる影の項目を取り入れた。この 8 項目について, 昭和52年修正の地形図と昭和54年調査の土 地利用図, 昭和53年作成の土㙥図を用いて,それぞれ100から250点のグランドトルスデータを UTM 座標 で拾い出した。各シーンの教師付分類ではこの同一のデータを用いている。 
佐 藤 哲 夫

第 7 表 2 段階に分けた場合の判別結果（シーン 2)

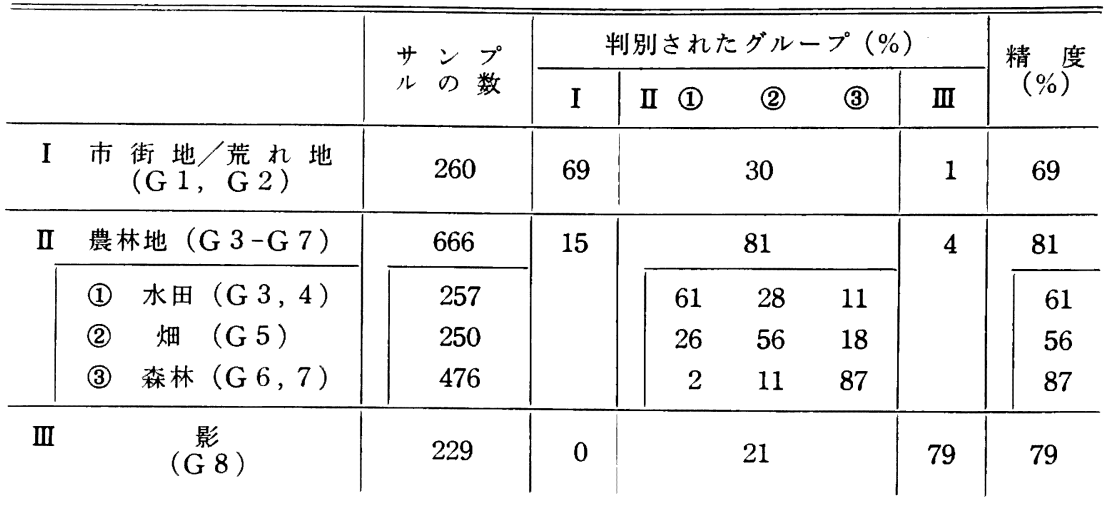

第 8 表 2 段階に分けた場合の判別結果（シーン 1 と 2 ）

\begin{tabular}{|c|c|c|c|c|c|c|c|c|}
\hline & & \multirow{2}{*}{\begin{tabular}{lll}
+ & \multicolumn{2}{l}{} \\
ル & の 数
\end{tabular}} & \multicolumn{5}{|c|}{ 判別されたグループ（\%) } & \multirow{2}{*}{$\stackrel{\text { 精 }}{(\%)}$} \\
\hline & & & I & II (1) & (2) & (3) & III & \\
\hline I & $\begin{array}{c}\text { 市 街 地/荒 れ 地 } \\
(\mathrm{G} 1, \mathrm{G} 2)\end{array}$ & 260 & 90 & \multicolumn{3}{|c|}{8} & 2 & 90 \\
\hline \multirow[t]{4}{*}{ II } & 農林地（G 3-G 7） & 333 & \multirow[t]{4}{*}{9} & \multicolumn{3}{|c|}{88} & \multirow{4}{*}{3} & 88 \\
\hline & (1) 水田 (G 3, 4) & 166 & & 81 & 16 & 3 & & 81 \\
\hline & (2) 畑 (G 5 ) & 241 & & 14 & 74 & 12 & & 74 \\
\hline & (3) 森林 (G 6, 7) & 260 & & 1 & 8 & 91 & & 91 \\
\hline & $\left(\begin{array}{c}\text { 影 } \\
\text { G } 8)\end{array}\right.$ & 108 & 1 & & 11 & & 88 & 88 \\
\hline
\end{tabular}

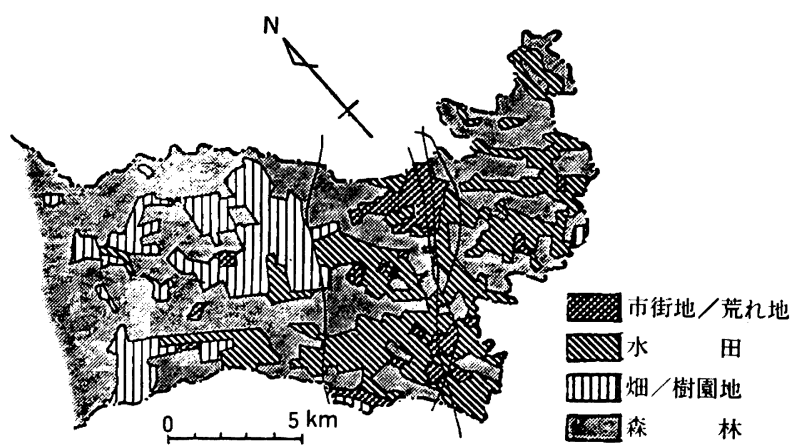

第 5 図黒磯市土地利用図

（国土地理院 20 万分の 1 土地利用図より）

変数として採用したのは Band 4 から Band 7 までの各バンドとその比演算で, 第 3 表に示した ${ }^{5)}$ 。 変数(6)，(7)は植物生 体量や葉面積指数を示す指標として多用 されている。変数(5)は晚秋期の葉色の変 化を示す指標として，また変数(10は土壤 有機物量を示す指標として有効であると 言われる。変数(8)，(9)は分光反射特性が 水型（長波長で低い）か，土壤・岩石型 （短波長で低い）か，または植物型（赤色 部で低い）かを表わすものとして採用し た。

79年のシーンを用い， 8 項目のグラン ドトルスを上記の 10 変数で最短距離法によって判別した結果を第 4 表と第 5 表に示す日)。シーン 1 は農地 と市街地の誤判別が少なく，シーン 2 は森林との誤判別が少ないという特徴が見られる。この傾向は季節 的なものと思われ，他のシーンにも認められた。

水田の判別の精度を上げるために，類似した項目を合わせ，多段階に分けて分類を行なった。ここでは 
各シーンとも，まず市街地・荒れ地， 水田・畑・森林, 影の 3 グループに 1 次分類を行なってから，2 次分類によ って水田，烟，森林の判別を行なうと いう方法で, 土地利用の分類画像を作 成した。グランドトルスの判別結果は 第 6 表，第 7 表に示した通りで，概ね 满足できる結果となった。また第 8 表 には 2 時期のデータ（20変数）を用い た場合の判別結果を示したが, 判別の 精度はかなり上がっている。

4) 分類画像の評価と合成
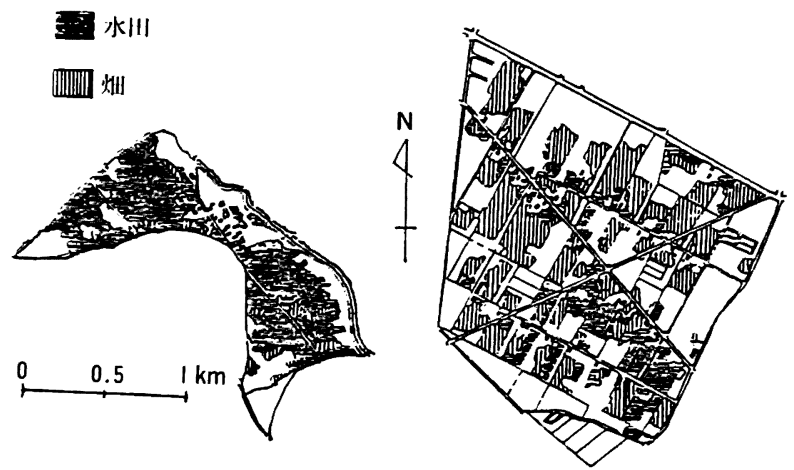

第 6 図黒磯市内の 2 集落の土地利用状況

シーン1，2 それぞれの分類画像と，両データ (20変数) を用いて作成した分類画像を写真 $1 *$ から 3 に示した。20万分の 1 土地利用図から作成した第 5 図と比較すれば，いすれも水田，畑の分布の特徵は一 致しており，稲作地域と畑作地域の明瞭な区分が確認される。集落単位で見た場合にも，やはり土地利用 の大まかな傾向の把握が可能だと見てよかろう。第 6 図に掲げた二つの集落に相当する地区を，2時期の データで作成した画像から切り出したのが写真 4 である。屋敷の配置や集落周辺に残された林地, 開拓村 の短冊状の地割り，用水路沿いの水田が見られる。

一方, 水田及び畑の面積の集計結果と1980年農業センサスの結果 ${ }^{2}$ を比較したのが, 第 9 表, 第10表で ある。市全体, 旧町村を比較の単位としても，その誤差は転作等実施面積の割合（杤木県で20\%）や，年 間農地転用率 (栃木県で0.5\%) に比べ，十分に大きい。なかには数パーセントの誤差で収まるものもある が、それはむしろ例外的であると思われる。集落単位ではその譔差はさらに大きくなる。集落別の集計結 果を回帰分析すれば，相関係数はいずれもかなり高く，2 時期のデータを用いる事によってさらに高まる

第 9 表 センサス結果（「稲を作った田」）と分類画像集計結果（水田）との比較

\begin{tabular}{|c|c|c|c|c|c|c|c|c|c|c|c|c|}
\hline & \multirow{2}{*}{$\begin{array}{c}\text { 現市計 } \\
\text { ha }\end{array}$} & \multirow{2}{*}{$\%$} & \multicolumn{2}{|c|}{ 旧町村 (1) } & \multicolumn{2}{|c|}{ 旧町村 (2) } & \multicolumn{2}{|c|}{ 旧町村 (3) } & \multicolumn{2}{|c|}{ 旧町村 (4) } & \multirow{2}{*}{$\left|\begin{array}{|c|c|}\text { 集落別面稓 } \\
\text { の相関倸数 }\end{array}\right|$} & \multirow{2}{*}{$\begin{array}{l}\text { 回㷌残差 } \\
\text { の標淮偏 } \\
\text { 差ha }\end{array}$} \\
\hline & & & ha & & ha & $\%$ & ha & $\%$ & ha & $\%$ & & \\
\hline センサス結果 & 2994 & 100 & 547 & 100 & 799 & 100 & 1080 & 100 & 568 & 100 & - & - \\
\hline シーン 1 & 3301 & 112 & 743 & 136 & 1039 & 130 & 812 & 75 & 707 & 125 & 0.852 & 16.6 \\
\hline シーン 2 & 2830 & 96 & 624 & 114 & 739 & 92 & 700 & 65 & 767 & 135 & 0.835 & 17.4 \\
\hline シーン 1 上2 & 3767 & 127 & 731 & 133 & 1045 & 131 & 1062 & 98 & 914 & 161 & 0.861 & 16.1 \\
\hline
\end{tabular}

第10表 センサス結果（「経営耕地面積」）と分類画像集計結果（水田, 畑）との比較

\begin{tabular}{|c|c|c|c|c|c|c|c|c|c|c|c|c|}
\hline & \multirow{2}{*}{$\begin{array}{c}\text { 現市計 } \\
\text { ha }\end{array}$} & \multirow{2}{*}{$\%$} & \multicolumn{2}{|c|}{ 旧町村 1) } & \multicolumn{2}{|c|}{ 旧町村 (2) } & \multicolumn{2}{|c|}{ 旧町村 (3) } & \multicolumn{2}{|c|}{ 旧町村 (4) } & \multirow{2}{*}{$\left|\begin{array}{l}\text { 集落別面積 } \\
\text { 重相関係数 }\end{array}\right|$} & \multirow{2}{*}{$\begin{array}{l}\text { 重回帰残 } \\
\text { 差, 標準 } \\
\text { 偏差ha }\end{array}$} \\
\hline & & & ha & & ha & $\%$ & ha & $\%$ & ha & $\%$ & & \\
\hline センサス結果 & 5471 & 100 & 860 & 100 & 1107 & 100 & 1437 & 100 & 2067 & 100 & - & - \\
\hline シーン 1 & 4923 & 90 & 950 & 90 & 1235 & 112 & 924 & 64 & 1814 & 88 & 0.946 & 25.6 \\
\hline シーン 2 & 5234 & 114 & 1163 & 135 & 1388 & 125 & 1109 & 77 & 2575 & 125 & 0.954 & 23.9 \\
\hline$シ ー ン 1 上 2$ & 6370 & 116 & 1108 & 129 & 1451 & 131 & 1283 & 89 & 2515 & 122 & 0.954 & 23.9 \\
\hline
\end{tabular}

*写真1〜 7 はロ絵にまとめた。 


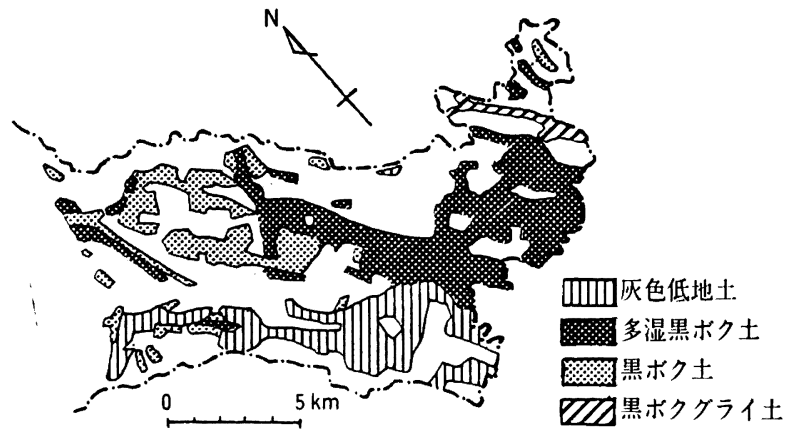

第 7 図黒磯市土壤分類図

（杤木県農業試験場 地力保全基本調査より）
が，他方残差もかなり大きい。

このように定量的な評価にリモート センシングを利用することはまだ難し いが，大まかな地城的傾向を把握する ことは比較的容易である。ここでも先 に述べた三つの問題を確認することが できた。写真 5 は79年の 2 時期のデー 夕から作成した水田土墒分類図で, 水 田の細分類を行なったうえ, 画像に平

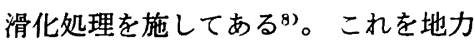
保全調查の結果（第 7 図）と比較する と, 特に大きな違いはないが, 山麓地 帯の多湿黒ボク土が画像では灰色低地

土に判別されていることに注目される。造成地の土壤が他の黒ボク土と多少異なっている可能性があると も考えられる。

写真 6 は79年時点での水田（水稲作付地）が80年，82年にどのように変化しているか示したものである。 変化のなかった部分は水色で，80年に畑（転換畑）となったものを黄色で，82年までに畑（転換畑）とな ったものを赤紫色で示した。79年，80年は二季節のデータを用いており，平滑化処理済みの画像を重ね合 わせたものである。これによれば，79年から80年にかけて増加した転作田（転換畑）が，北部の酪農地区 に集中している事が確認される。また同じ酪農地区，集落であっても，那須疎水などの用水路沿いの水田 が転作されずに残されていることも特徴的と言える。それに対して，80年から82年にかけての新しい転作 田（転換畑）は，市内全域に分散しており，際立った特徵を持っていない。稲作地区のなかでは，和牛生産 組織や麦作集団の活動が活発な集落で，多少まとまった転換畑が見られるが，目立つほどではない。酪農 家を主体とした転作が限界となって, 現在の水田利用の変化が稲作地区の農家集団の複合化を中心として いるといら状況を反映しているものと考えられる。

写真 7 は, 上と同様の処理によって 79 年の農地のうち, 80 年, 82 年までに市街地・荒れ地となった部分 を抽出しようとしたものである。東北新幹線の駅設置（那須塩原駅）が決まっていた，南部の東那須野駅 周辺での変化が特に目立っているが，数年間の変化にしては急激すぎて，農地の潰廃のみが表現されたも のとは考えにくい。

\section{IV. 結論と展望}

上記のランドサットデータの分析事例で，今後の改良が最も強く望まれるものは，定量的な安定性であ る。現状では，あるシーンに対して定量的に精確性の高い分類法を見いだしても，それが他のシーンに対 しても同様の精確性を保証するとは限らない。大気やセンサーの状態による画質の不良，不均質の他に， 作物の生育にともなう土地被覆の変化によって，定型的な処理が困難になっているという部分もあると思 われる。これに対しては，季節ごとにグランドトルスデータや分類法を変えることによって，定型的な処 理による分類精度を高めることが可能だと思われるが，それは今後の課題である。

目下のところ，全てを定型的な処理に任せたのでは，土地利用調査として十分な結果は得られないと言 える。基䃈的な技術と言われる土地利用判別についても，現地の状況に照らし合わせて，適宜判断し，修 正を行なう必要があるわけで，リモートセンシングが現地調査に完全にとって代わるということはあり得 ない。むしろ土地利用調査そのものではなく、リモートセンシングによって土地利用調查を行なうための 現地調査の必要すらあろう。 
他方, 定性的な資料としては, 衛星リモートセンシング程度でも利用のメリットは十分大きく, 土地利 用変化に関する新たな要因分析の契機を生み出す可能性もある。例えば，同一集落内でどのような場所の 土地利用変化が大きいか, 耕地利用度が高いか, 団地化が進んでいるか, 等々の問題に対し, ある程度一 般的な傾向が見いだせれば，より精緻な調査に発展させることができよう。現在の衛星りモートセンシン グは，周期的な観測と言うには余りにも不安定だという見方もあるが，時系列的な分析で歴史的な資料以 外の使い方ができるという点では, 大きな進歩であると言えよう。さらにこれまでの広域の農業的土地利 用調査法に比べて，省力化が格段に進んでいることも高く評価されて良い点だろう。

1）JICA を通じて行なわれているインドネシアの農業開発リモートセンシング計画では，ランドサ ットデータから土地被覆図, バイオマス分級図, 土壤水分図などの主題図を作成し, 標高その他 の国土情報と合わせて農業開発適地評価図を作成している。

2) リモートセンシング技術センター（RESTEC）では，1984年 5 月からフロッピーディスクによる データの供給を行なっている。フロッピーディスクには，1 倍モードで約 $25 \mathrm{~km} \times 20 \mathrm{~km}$ の範囲 のデータが収納されている。

3） 1979年 1 月から1983年12月までのランドサット 2,3 号のデータ（パス 113-122）と1983年 1 月か ら1984年12月までのランドサット 4 号のデータ（パス 105-114）をデータカタログで整理して作 成した。

4）経済的土地分級は一定の土地ないし地域を農業経営と結びつけて，紷合的かつ将来期待性の観点 から区分するため, 区分の指標としては将来性を規定する要因を重視する。従って, 主題と指標 を一致させる実質地域区分の枠外にはみ出すわけで，形式地域区分ということになる。米国の経 済的土地分級を日本に紹介したのは岩片（1960）であるが，理論と実証を含めて総合的にまとめ た文献としては，金沢（1973）が詳しい。

5）変数の採用にあたっては，江森ほか（1979），福原ほか（1979），妹尾ほか（1983）を参考にした。

6）三次たたみ込み法で同しメッシュにリサンプリングした場合，画像の判別精度は最近隣法による 画像よりも低い。写真画像の場合には, 三次たたみ込み法で作った画像の方が見やすいと言われ るが, 統計処理による分類画像を作る場合には，原デー夕を破壊しない最近隧法の方が有効と言 える。

7） 1980年農業センサスは1979年の実績を調查したものである。属人的な集計が行なわれるので，厳 密には地図上で求めた面積とは一致しない。また耕地面積についても, 農業センサスが最も正確 であるとは言えず，自治体や農業団体の調查した数值の方が実情に近い場合が多い。

8）分類画像に平滑化処理を施すことで，パターンの把握が容易になると言われる。ここでは majority filter (SCHOWENGERDT 1983) と言われる処理を行なった。

\section{参考文献}

秋山低・深山一竹(1984)：人工衛星データによる農業開発適地選定一パターン法による土地評価シ ステムの北スマトラへの適用一. 日本作物学会紀事, 53（別号 2), p. 128-129.

一・芝山道郎 (1985)：宸業用リモートセンサーの開発と利用. 日本リモートセンシング学会誌, $5(1)$, p. $77-84$.

地球観測センター編(1982)：地球観測データ利用ハンドブックリリモトセンシング技術センター, 178p.

江森康文ほか(1979)：姆地のリモートセンシングにおける計測と画像処理システムに関する研究。農 林水産業特別試験研究费補助金による研究報告書, 136p.

福原道一・林 成周・安田嘉純・江森康文・飯坂变二(1979)：土壤図作成のための前処理とチャンネ ルの選択. 日本写真測量学会秋季学術講演会, 講演要旨, p. 103-106.

深山一弥・佐藤 博・安田嘉純・江森康文 (1983)：ランドサットMSS データを用いた水稲冷害分布 の調査法. 農土論文集, 105, p. 27-35.

・安田嘉純(1981)：ランドサットデータ利用による水稲冷害調查に関する研究. 日本写真測量学 会秋季学術講演会, 講演要旨, p. 29-32. 
HORD, R. M. (1982) : Digital Image Processing of Remotely Sensed Data. Academic Press, 256p.

妹尾俊夫・岩浪英二・田中總太郎・杉村俊郎 (1983)：比演算を施した 2 季節のランドサットMSS デ ータによる広域山地の林相区分. 日本リモートセンシング学会誌, 3(3), p. 55-64.

岩片磯雄 (1960)：アメリカにおける経済的土地区分の調查研究。国際食糧農業協会, 100p.

神山啓治・宇田川武俊(1981)：ランドサットテータの農地情報への利用一麦作付け面䅡の推定一, 日 本作物学会紀事, 50 (別号 2), p. 225-226.

金沢夏樹編著 (1973)：経済的土地分級の研究. 東京大学出版会, 372p.

国際協力事業団(1983)：インドネシア共和国農業開発リモートセンシング計画報告書, 第 1 分冊, 205p.

LINDGRen, D. T. (1985) : Land use planning and remote sensing. Martinus Nijhoff Publishers, $176 \mathrm{p}$.

中島 箶(1982)：宇宙から地球を探る。同文書院，244p.

那須 充(1981)：ランドサットデータの農業開発への応用一北イエメンにおけるヶーススタディー, 写真測量とリモートセンシング, 特集号 I, p. 56-64.

日本リモートセンシング研究会編(1981)：画像の処理と解析, 共立出版, $267 \mathrm{p}$.

農林水産技術会議事務局編 (1964)：土地利用区分の手順と方法. 農林統計協会, 432p.

斎藤元也・境 忍・秋元文重・山本 博(1985)：ランドサットMSS データからの土壌情報の抽出に よるカラー合成と土壤水分変化の把握. 写真測量とリモートセンシング, 24(1), p. 4-12.

SchowengerdT, R. A. (1983): Techniques for Image Processing and Classification in Remote Sensing. Academic Press, 249p.

芝山道郎・渡辺利通・棟方 研 (1981) : ランドサットデータによる農作物広域作況予測手法の開発 一水稲作付エリアの推定の試み一. 日本作物学会紀事, 50 (別号 2), p. 227-228.

高橋正郎・森 昭(1978)：自治体農政と地域マネイジメント，明文書房, 282p.

高畑 滋・福原道一・深山一弥・斎藤元也・林 成周(1978)：リモートセンシングによる有珠山噴火 農地被害調查に関する研究. 北海道農業試験場研究報告, 123, p. 101-111.

和田照男 (1980)：現代農業と土地利用計画. 東京大学出版会, 290p.

渡辺利通・芝山道郎・棟方 研 (1981)：ランドサットテータによる農作物広域作況予測手法の開発 -1980 年度冷害の被害程度の推定一. 日本作物学会紀事, 50 (別号 2), p. 229-230.

安田嘉純・江森康文・飯坂䛊二・福原道一(1980)：ランドサット・データによる土䘫図の作成. 写真 測量とリモートセンシング, 19(4), p. 16-21.

（1985年 8 月 6 日受理） 